\title{
Are local residents able to contribute to tourism governance? - impacts and perceptions in Cape Verde
}

\author{
Edgar Bernardo* Filipa Jorge**
}

Universidade de Trás-os-Montes e Alto Douro (Portugal)

\begin{abstract}
Tourism planning and development necessarily entails efficient governance. The structure of such governance system includes the key players in order to ensure that all stakeholders are heard, contribute to the plan and participate in its implementation. This article introduces Cape Verde, a country with significant tourism growth and results, and it focuses on the case study of Boa Vista island. This paper is the result of a 5-year research that applied a mix methodology based on field work and interviews content analysis framed statistically and comprehensively in a mixed method analysis. This study demonstrates that communities are able to identify the negative and positive impacts of tourism development. Boa Vista has a community that is a practical example that locals able to recognize the existing problems and contribute to the future path to sustainable and truly representative development in sub-Saharan Africa.
\end{abstract}

Keywords: Tourism impacts; Perceptions; Boa Vista; Cape Verd; Governance.

Podem os residentes locais contribuir para a governança turística? - impactos e perceções em Cabo Verde

Resumo: O planeamento e o desenvolvimento do turismo implicam, necessariamente, uma governança eficiente. A estrutura desse sistema de governança inclui os principais atores, a fim de garantir que todas as partes interessadas sejam ouvidas, contribuam para o plano e participem de sua implementação. Este artigo apresenta Cabo Verde, um país com significativo crescimento em resultado da atividade turística, e foca no estudo de caso da Ilha da Boa Vista. Este trabalho é o resultado de uma pesquisa de 5 anos que aplicou uma metodologia mista baseada em trabalho de campo e entrevistas de análise de conteúdo enquadradas estatisticamente e de forma abrangente em uma análise de método misto. Este estudo demonstra que as comunidades são capazes de identificar os impactos negativos e positivos do desenvolvimento turístico. Boa Vista tem uma comunidade que é um exemplo prático do reconhecimento dos problemas existentes confirmando o seu valor no caminho futuro para o desenvolvimento sustentável e verdadeiramente representativo na África Subsaariana.

Palavras-chave: Impactos; Perceções; Boa Vista; Cabo Verde; Governança.

\section{Introduction}

Cape Verde is yet another example of a country that is looking at tourist activity as a rapid way to modernize its society by boosting its economy that still today is very dependent on remittances and foreign aid. This quest for economic and social balance, and for sustainability, is reflected in its recent and young history as an independent country seeking to achieve its goals (Sarmento, 2008), a common strategy in island territories with a fragile economy and industry (Vellas, 1997; Kakazu, 2007).

Many countries aim for tourism development, hoping that it will reform and promote immediate development, as if by magic (Brown, 1998), but the success of this strategy is yet to be proven, especially

Centro de Estudos Transdisciplinares para o Deenvolvimento (CETRAD) Universidade de Trás-os-Montes e Alto Douro; E-mail: edgaracb@utad.pt

* Centro de Estudos Transdisciplinares para o Deenvolvimento (CETRAD) Universidade de Trás-os-Montes e Alto Douro;

E-mail: filipajorge@utad.pt 
in African countries. Even in contexts of apparent success, research seems to imply that only the elites and the middle class benefit from increased incomes (Azarya, 2004). To make things worse, the same research implies that this strategy widens the gap between classes, failing the sustainability goal in these societies (Redcliff, 1992).

As an aggravating circumstance, many communities affected by the process of touristisation end up suffering the already known negative impacts such as increased crime, real estate speculation, loss of traditional activities, acculturation processes, etc. Even at the national level, the data seem to point to sporadic or intermittent economic growth in many destinations. The UNWTO data itself (2016) shows that, comparing with the rest of the World, the African continent continues to show a percentage of low growth, currently at $5 \%$, just $1 \%$ more than the currently unstable middle eastern region. It should be noted that the bulk of this growth continues to be concentrated in the South and Northwest of the continent, leaving the rest of Africa, and in particular Sub-Saharan Africa, apart from the large tourism contributions to GDP.

Still, countries like Cape Verd have changed their economic and political models following the global neo-liberal model in order to welcome international tourism. From its independence in 1975 until 1990 the country followed an isolationist model based on the internal market, juxtaposed to its pro-Soviet economic model, but with the legislative elections and a new party in the government the trend changed completely. This process is directly related to tourism since this is a central objective from the fourth national development plan (1997-2000) onward, a period that was marked by the proliferation of business creation and infrastructures linked to tourism.

The data is clear, in 1990 the country received 21 thousand tourists and in 2007 it rose to 333 thousand, most of them from the UK, Italy and Portugal (INE-CV, 2015), and currently the number is approaching 700 thousand, most of them still from Europe, seeking an all-inclusive tourism destination (Lopez-Guzman, Ribeiro \& Agüero, 2015). This resulted in an impressive 44.9\% impact on GDP, accounting for $39 \%$ of total jobs. Of course, this growth and economic development has brought about an improvement in basic infrastructure, education and training, health, etc. and an improvement in numerous social aspects that allowed the country to recently join the middle-developing countries list, a well knowned rapid tourism growth based on tax and banking reforms (Twining-Ward, 2010).

Most of the international visitors are concentrated in the beach tourism islands of Sal and Boa Vista, the great bet since the fifth national development plan that also created the Higher Institute of Tourism and Hospitality, the School of Hospitality and the Tourism Development Society of the Boa Vista and Maio Islands (SDTIBM). This concentration is clearly reflected in the statistical data of recent years, for example in 2017, the island of Sal and Boa Vista together accounted for $90 \%$ of the total overnight stays in the country.

The rapid changes brought about by the growth of tourism activity on the island of Boa Vista, an island whose economy was based on fishing and subsistence agriculture. Bernardo (2015) reported several impacts perceived by residents in previous work, namely positive (job creation, infrastructure, migration, improvement of living conditions, economic growth, cultural exchange, increase of professional levels, entry of foreign exchange, culture revitalization) and negative (increased crime, unequal division of benefits, uncontrolled growth, rising prices, changes in morality, labour exploitation, discrimination against migrants, real estate speculation, lack of infrastructure, loss of authenticity, increased corruption, local attitudes towards tourism, dependence on tourism, increased pollution, loss of rights of residents, destruction of nature, changes in consumption patterns, loss of local language, abandonment of traditional practices). The author concluded that there was a predominance of positive economic impacts and, on the contrary, a predominance of social negative impacts, and in both cases the environment related impacts were neglected. This predominantly negative perception of tourism has led to two types of prevailing postures, one of resistance and the other of adaptation, i.e. those that were adapted to the new dynamics and those who oppose mass tourism model.

This article does not intend to make known individually these perceived tourism impacts of the island's residents, but rather to present the statistically significant differences that occur between groups, seeking also to justify these perceptions using both field work and secondary data. We intend to prove that even just considering the statistically prevalent perceptions of impacts, residents are aware and recognize both the advantages and disadvantages of tourism. These results are compared with those of other referenced authors or in a similar context. In the next section we approach and justify the applied methodology, followed by the results presentation, and later we discuss the lessons and implications of the results. 


\subsection{Methodology}

This article is an integral part of an investigation into the discourses, impacts and reactions to tourism on the island of Boa Vista in Cape Verde. A project funded by the Foundation for Science and Technology of Portugal (FCT), also associated with the Centre for Research and Studies in Sociology of the University Institute of Lisbon (CIES-IUL). The methodology selected was mixed methods with a qualitative or intensive focus, involving fieldwork between 2012-2014. In this period, a total of 96 semi-directed interviews were applied, related to the residents' perception about the impacts of tourism on the island and its community. The interviews lasted between 30 to 90 minutes and were applied in the location and time of their convenience.

The answers were categorized into 30 dependent variables divided into positive impacts, namely, Job Creation, Infrastructure Creation, Migration, Quality of life Improvements, Economic Growth, Cultural Exchange, Professional Levels Increase, Currency Entry, Traditions Revitalization, Environment Protection, and negative impacts: Craft Demand, and Crime Increase, Unequal Benefits Sharing, Uncontrolled Growth, Price Increase, Moralities Change, Labour Exploitation, Discrimination Towards Immigrants, Real Estate Speculation, Lack of Infrastructure, Loss of Authenticity, Corruption Increase, Locals Attitude towards Tourism, Tourism Dependency, Pollution Increase, Residents Rights Violation, Nature Destruction, Changes in Consumption Patterns, Loss of Local Language, Traditions Abandonment.

As for the independent variables we used socio-demographic data: gender, age, nationality, residence, schooling, professional situation, residence, group (type of residents). Groups of respondents were considered taking into account the characterization variables of the sample. We used the one-way ANOVA Test was used to test whether there are statistically significant differences between the different groups average (Hair, Black, Babin, Anderson, \& Tatham, 1998).

\subsection{Results}

As for the sample, it is characterized by 96 individuals, 58 of whom are male, about $60.4 \%$, and the rest are female. In terms of origin, 78.1\% are Cape Verdean natives, $19.8 \%$ are from Europe (Portugal, Spain, France and Italy), and the remaining 2.1\% from other countries (from Brazil, and from Angola). In terms of residence, the majority of interviewees lived in urban areas (71.9\%) and the rest in rural. Schooling was another of the sociodemographic considered characteristics. This was divided into 6 categories, starting from "up to primary education" to "higher education". A large number of interviewees were included in the category of "higher education", about $46.9 \%$.

This is justified by the fact that most of the foreign elements, operators, and political actors interviewed had higher education, as well as some of the natural residents of Boa Vista and the other islands being secondary school teachers. Regarding age, only adult individuals were considered, the youngest being 20 years old and the oldest being over 70. In this way, the interviewees were subdivided into 6 categories (20-29, 30-39, 40-49, 50-59, 60-69, 70+). The following characteristic refers to the professional situation, where 5 categories were considered: "employed" (64.6\%), "unemployed" (5.2\%), "self-employed" (22.9\%), "retired" domestic "(1\%).

The last socio-demographic characteristic considered was the "Group". This refers to the origin of the residents (natives of Boa Vista, other islands, and resident aliens, and tourism "operators"). Here, we highlight the prevalence of "Boa Vista natives", which represents approximately $61.5 \%$, with the remainder being very close in percentage, varying between $11.5 \%$ of the "operators" and $14.6 \%$ of "resident aliens". 
Table 1: Demographic Information of Sample

\begin{tabular}{|c|c|c|c|}
\hline Characteristics & & Frequency & $(\%)$ \\
\hline \multirow{2}{*}{ Gender } & Male & 58 & 60,4 \\
\hline & Female & 38 & 36,6 \\
\hline \multirow{6}{*}{ Age } & $20 \sim 29$ & 20 & 20,8 \\
\hline & $30 \sim 39$ & 38 & 39,6 \\
\hline & $40 \sim 49$ & 20 & 20,8 \\
\hline & $50 \sim 59$ & 7 & 7,3 \\
\hline & $60 \sim 69$ & 6 & 6,3 \\
\hline & 70 & 5 & 5,2 \\
\hline \multirow{2}{*}{ Nationality } & Capeverdian & 75 & 78,1 \\
\hline & Other & 21 & 21,9 \\
\hline \multirow{2}{*}{ Residence } & Urban & 69 & 71,9 \\
\hline & Rural & 27 & 28,1 \\
\hline \multirow{4}{*}{ Schooling } & Up to Primary School & 19 & 19,8 \\
\hline & Preparatory School & 15 & 15,6 \\
\hline & High School & 16 & 16,7 \\
\hline & University (or Higher Education) & 46 & 47,9 \\
\hline \multirow{5}{*}{ Professional Situation } & Employed & 62 & 64,6 \\
\hline & Unemployed & 5 & 5,2 \\
\hline & Self-employed & 22 & 22,9 \\
\hline & Retired & 6 & 6,3 \\
\hline & Domestic & 1 & 1 \\
\hline \multirow{4}{*}{ Group } & Boa Vista Natives & 59 & 61,5 \\
\hline & Other islands Natives & 12 & 12,5 \\
\hline & Resident Natives & 14 & 14,6 \\
\hline & (tourism) Operators & 11 & 11,5 \\
\hline
\end{tabular}

This sample assumed a higher prevalence of residents natural to Boa Vista, since the original research objective was to determine the perceptions of these natives who, according to the available statistical, the majority were natives, namely data from the 2010 National Censuses. However, the actual majority of the residents living at Boa Vista in 2012 came from other islands, in fact, it was found that the statistical data was so deeply outdated that the population had tripled in the last 3 years.

With the information extracted from the interviews, a database was created with simplified units divided into 7 variables of characterization of the sample and a second block of 30 variables, of which 11 are related to the positive impacts and 19 to the negative impacts of tourism. These impacts were defined according to the known literature, and some others were added when they did not fit the variables established in the literature.

The results will now follow, which in turn, will be contextualized using information from the field work and excerpts from interviews, and finally compared with other researches. Using the one-way Anova test, it was tested whether perceptions of the positive and negative impacts of tourism are significantly different between groups $(p<0,05)$. Characterization variables were used to divide the sample into groups. Regarding the positive impacts, in Table 2 , we present tests that have been shown to be statistically significant. 

Table 2: One-Way Analysis of Variance Examining Differences
in Positive Impacts based on age and residence group

\begin{tabular}{|l|l|l|}
\hline Variables & \multicolumn{1}{|c|}{ Age } & \multicolumn{1}{c|}{ Group } \\
\hline Job Creation & $\begin{array}{l}\mathrm{F}(5,96)=2,590 \\
p=0,031\end{array}$ & $\cdots--$ \\
\hline Quality of Life Improvements & $\cdots--$ & $\begin{array}{l}\mathrm{F}(3,96)=2,863 \\
p=0,041\end{array}$ \\
\hline
\end{tabular}

$p<0,05$

The variable "Job Creation" is perceived differently by at least one age group. The youngest are the age groups (20-29 and 30-39) who more often say that tourism has created more employment (Table 1). The variable "Improvement of Living Conditions" is perceived differently also by at least one residence group.

Regarding the negative impacts (see table 3) we present tests that have been shown to be statistically significant. The variable "Unequal Division" is perceived differently in at least one of the considered schooling levels, in at least one group of residents and in at least one of the categories of the professional situation. Generally speaking, the higher the level of education, the higher the perceived negative impact (see Figure 3).

Figure 1: Relative Frequencies of Tourism Impacts (negative and positive) by Age

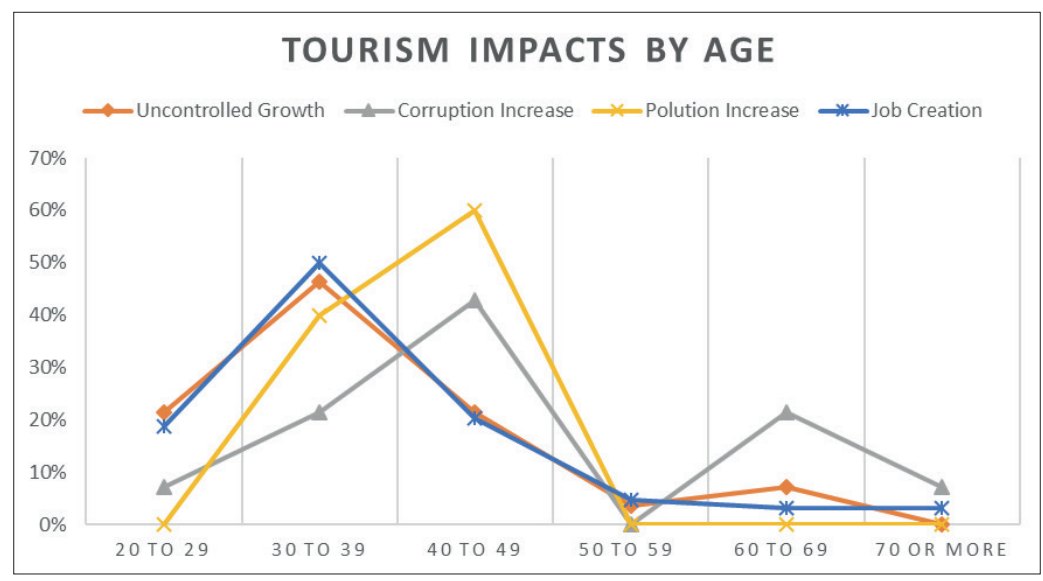

The variable "Uncontrolled Growth" is also perceived in a significantly different way by at least one age group, in at least one category of schooling, in at least one group of residents. This perception was much more mentioned by the younger age groups, from 20 to 29 and 30 to 39, than in the older age groups (see figure 1). The higher the education level, the greater the mention of this negative impact (see figure 3).

The "Increase in Corruption" was also significantly different among the age groups considered, among the educational levels considered as well as among the groups of residents considered in the study. We can see that the age group that mentions "Increase in Corruption" the most is 40 to 49 years, in contrast to the age group from 50 to 59 years old, which does not mention this impact at all (see Figure 1). As far as level of education is concerned, mostly individuals who have completed high-school (see Figure 3).

The variable "Increase in pollution" is significantly different between different age groups, since only two age groups mention this negative impact, specifically the range from 30 to 39 and the range from 40 to 49 years (see Figure 1). The variable "Authenticity" has been perceived in a significantly different way by the different nationalities and by the two categories of place of residence. Taking into 
account figure 6 it is noticeable that it is the residents in urban environment who most mentions this negative impact of tourism.

Figure 2: Relative Frequencies of Tourism Impacts (negative and positive) by Schooling

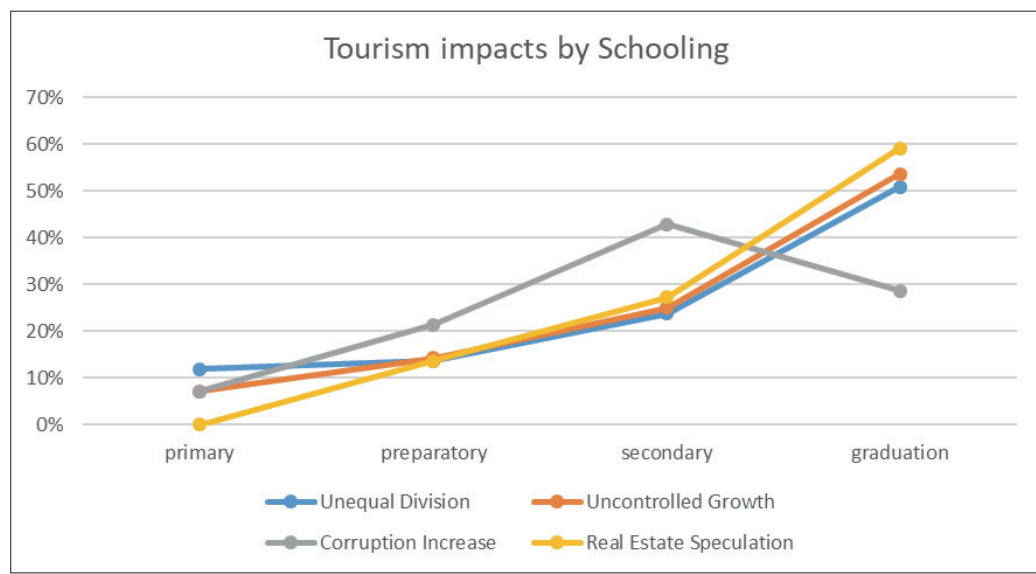

Figure 3: Relative Frequencies of Tourism Impacts (negative and positive) by Nationality

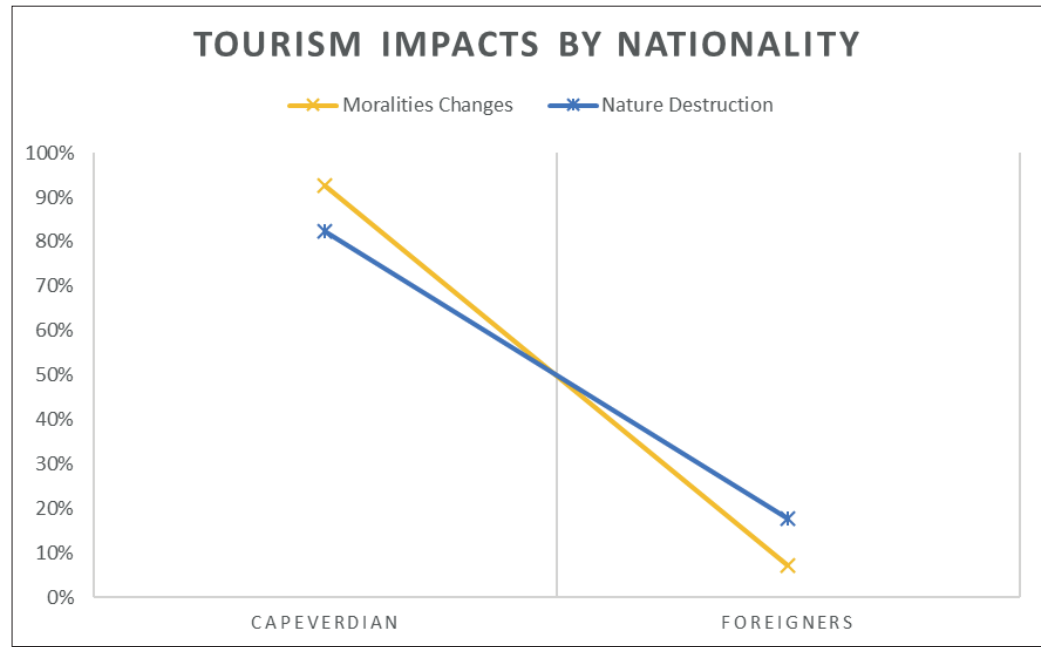

The perceptions of "Changes to morality" have been found to be significantly different in the group of Cape Verdians and foreigners, the latter hardly mentioning this negative impact of tourism (see Figure 2). When we consider the variable "Destruction of nature", this is significantly different when we analyse the different groups of residents, since it is the foreign residents in Boa Vista who mentions the most this negative impact of tourism, as can be seen in Figure 4.

The variable "Real Estate Speculation" reveals to be significantly different between the educational levels considered in the study and there are still significant differences between genders. As can be seen in Figure 3, the higher the level of schooling, the greater the perceived negative impact of tourism. Regarding this variable, it is the male individuals who most perceive this impact, as can be seen in Figure 5 . 
Figure 4: Relative Frequencies of Tourism Impacts (negative and positive) by Group

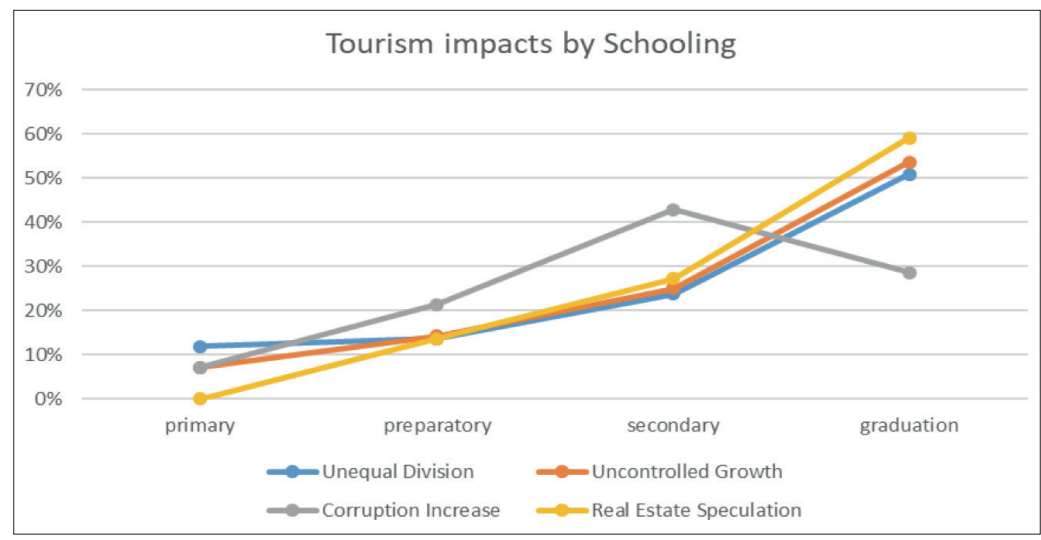

Figure 5: Relative Frequencies of Tourism Impacts (negative and positive) by Gender

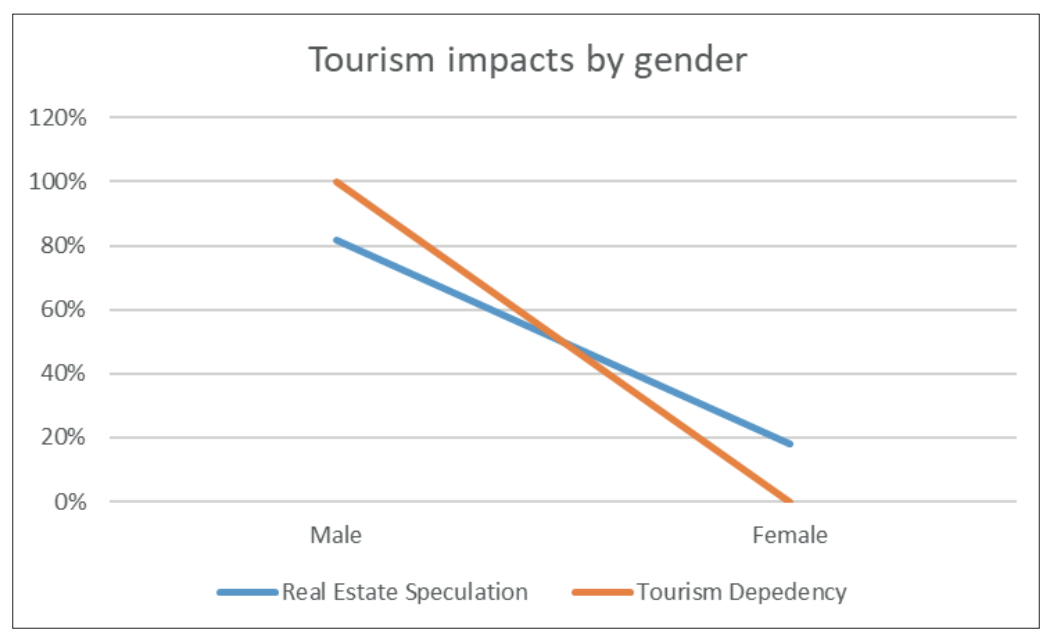

Figure 6: Relative Frequencies of Tourism Impacts (negative and positive) by Residence

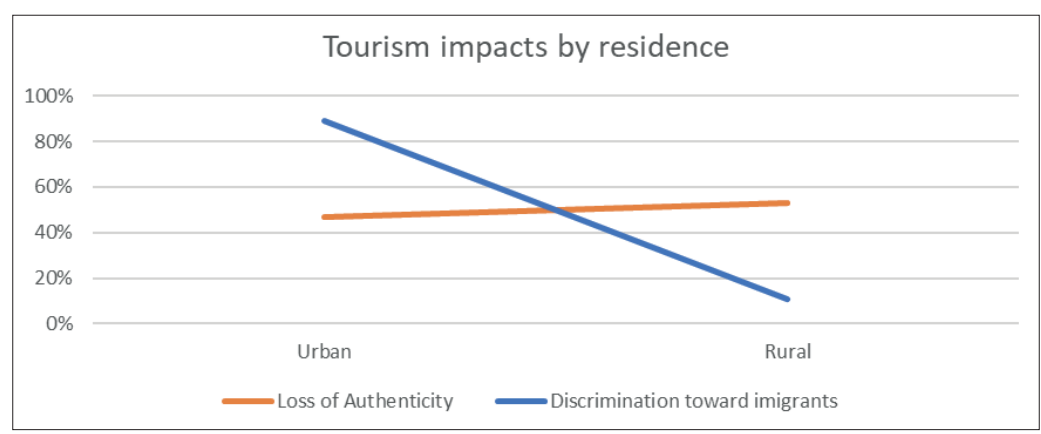


With respect to the variable "Tourism Dependence", this one reveals to be perceived differently by the two genders. It is only men who mentions this negative impact of tourism (Figure 5). When we analysed the variable "Discrimination of Migrants" we also noticed that there are only significant differences between the two categories of place of residence of the individuals, and there is also similarity of the previous variable are the residents in urban environment mention considerably more this impact than the residents in rural environment, as expressed in Figure 6. Of the 11 positive impacts initially identified, only 2 were statistically significant, and of the 19 negative impacts, 10 proved to be equally significant.

Table 3: One-Way Analysis of Variance Examining Differences in Negative based on age, nationality, education, residence group, gender, local of residence and professional situation)

\begin{tabular}{|c|c|c|c|c|c|c|}
\hline Variables & Age & Nationality & Schooling & Group & Gender & Residency \\
\hline $\begin{array}{l}\text { Unequal } \\
\text { Sharing }\end{array}$ & $-\cdots-\cdots$ & $-\cdots-\cdots$ & $\begin{array}{l}\mathrm{F}(3,96)= \\
3,619 \\
p=0,016\end{array}$ & -..--.- & -...-.- & $-\cdots-\cdots$ \\
\hline $\begin{array}{l}\text { Uncontrolled } \\
\text { Growth }\end{array}$ & $\begin{array}{l}\mathrm{F}(5,96)=2,416 \\
p=0,042\end{array}$ & -...- & $\begin{array}{l}\mathrm{F}(3,96)= \\
6,844 \\
p=0,000\end{array}$ & -...-.- & -.--..- & -.--.-. \\
\hline $\begin{array}{l}\text { Corruption } \\
\text { Increase }\end{array}$ & $\begin{array}{l}\mathrm{F}(5,96)=3,076 \\
p=0,013\end{array}$ & --.--.- & $\begin{array}{l}\mathrm{F}(3,96)= \\
3,448 \\
p=0,020\end{array}$ & --.---. & --.--.-- & $-\cdots---\cdot$ \\
\hline $\begin{array}{l}\text { Pollution } \\
\text { Increase }\end{array}$ & $\begin{array}{l}\mathrm{F}(5,96)=2,729 \\
p=0,024\end{array}$ & -..... & ...... & -.-.-.. & -.-.-.- & -...-. \\
\hline $\begin{array}{l}\text { Loss of } \\
\text { Authenticity }\end{array}$ & $-\cdots-\cdots$ & $-\cdots-\cdot-$ & -.-.-.- & --.--.- & -.--.-. & $\begin{array}{l}\mathrm{F}(1,96)= \\
6,595 \\
p=0,012\end{array}$ \\
\hline $\begin{array}{l}\text { Moralities } \\
\text { Changes }\end{array}$ & $-\cdots-\cdot$ & $\begin{array}{l}\mathrm{F}(1,96)= \\
9575 \\
p=0,003\end{array}$ & -.--.-. & ----.-. & --.--.- & $-\cdots---\cdot$ \\
\hline $\begin{array}{l}\text { Nature } \\
\text { Destruction }\end{array}$ & $-\cdots---$ & $\begin{array}{l}\mathrm{F}(1,96)= \\
5,903 \\
p=0,019\end{array}$ & -..-.-. & $\begin{array}{l}\mathrm{F}(3,96)=2,918 \\
p=0,038\end{array}$ & -.-.-.- & -...-- \\
\hline $\begin{array}{l}\text { Real Estate } \\
\text { Speculation }\end{array}$ & -..--.. & -..-.- & $\begin{array}{l}\mathrm{F}(3,96)= \\
2,937 \\
p=0,037\end{array}$ & -.--.-. & $\begin{array}{l}\mathrm{F}(1,96)= \\
5,675 \\
p=0,019\end{array}$ & -..-.-. \\
\hline $\begin{array}{l}\text { Tourism } \\
\text { Dependency }\end{array}$ & -...-.. & -...-. & -.---.- & -..-.-. & $\begin{array}{l}\mathrm{F}(1,96)= \\
8,708 \\
p=0,004\end{array}$ & -..-.-. \\
\hline $\begin{array}{l}\text { Discrimination } \\
\text { toward } \\
\text { immigrants }\end{array}$ & $-\cdots-\cdots$ & $-\cdots-\cdots$ & -..-.-. & -.-.-.- & -.--.-. & $\begin{array}{l}\mathrm{F}(1,96)= \\
6,186 \\
p=0,015\end{array}$ \\
\hline
\end{tabular}

$p<0,05$

The purpose of this article is not related to this verification and identification and posterior conclusion, but rather we intend to contextualize and justify each of these statistically significant impacts. This objective allows a greater understanding of the origin of these perceptions, as well as, fits the reality of the island of Boa Vista, lived and felt, that escapes a purely statistical analysis. Using some excerpts from interviews, secondary data and descriptions, collected over 2 years of participant observation in the field, between 2012 and 2014, we will discuss the processes that motivates and justifies the above-mentioned perceptions, starting with the positive impacts.

Until the 1990s the island of Boa Vista experienced a slow but steady decline in its economy, aggravating the economic conditions of its populations, forcing their younger generation to migrate to Europe and the United States. From the beginning of the XXI century, with the construction of the international airport, the various mass tourism hotels and other infrastructures appeared and, with it, multiple employment opportunities, especially for young adults: "The island of Boa Vista is as the 
country's lowest unemployment and is the one that most contributes to the national GDP at the moment, and solves the problems of the country of unemployment."(URMREB34, 2014).

The data shows that there are two different blocks, the 3 younger groups (20-29, 30-39, 40-49) and the remaining ones, that is, job creation is particularly relevant for those who are active or beginning their professional careers. This is in line with the latest WTTC data (2016) that point to tourism as responsible for about $45 \%$ of the employment in Cape Verd.

Improvement of living conditions is the second and final positive impact to be referred and includes the access to new or improved services, increased purchasing capability, security, etc.: "It is noted that there is a better quality of life for people. The people go out, in the old days there were no Cape Verdeans in the restaurants." (URHOP47, 2014). This result can also be seen on other researches such as Liu \& Var (1986), Akis et al (1996), Chen et al. (2004), etc. Cape Verde's enormous positive progress in the Human Development Index over the last 20 years is inseparable from its focus on a neo-liberal economic model based on tourism.

This recognition is evident in the test carried out that highlights the residence group "operators" as the ones that most mention these impacts at a relative distance from the other groups. It is always present in the discourses and arguments of foreign operators and investors this idea of improvement of living conditions, however, the test proves that this perception is not at all shared with all other groups that reside on the island. This difference will be better understood when considering some of the perceived negative impacts that directly oppose this idea of success.

Now let's consider the negative impacts, starting with the "uneven division of benefits". This reflects the perception that the country's economic growth, significant foreign exchange inflow, and job creation do not necessarily mean that the wealth produced is distributed among the local community in an equitable way, or at least minimizing the existing differences. This impact is exacerbated by the monopoly of some foreign companies in some services, namely the all-inclusive hotels, and by the need to raise capital to invest in new businesses, a hard process that makes difficult for locals and nationals to create and grow businesses that allow them to take advantage of the opportunities: "At this moment everything is opening: new operators, new restaurants and new businesses around tourism, but it is relevant to point out that most of them are foreigners!" (URMREB34, 2014). Opportunities for the locals are small but still highly disputed among themselves, migrants from other islands, and immigrants from the African coast, particularly in small businesses such as the sale of handicrafts, for example. The groups with the highest educational level are the ones who most support this perception, which can be justified by the fact that they can't take advantage of existing opportunities, partly because they do not see their educational level reflected in the job or position they occupy. There are several Cape Verdean graduates who are not promoted above certain positions in the hotels, or deprecated by European foreigners, an example of this would be the fact that, although they have the right levels of education, they aren't allowed to go above head of reception.

Concerning the "corruption increase" impact, which refers to active or passive participation in illegal or immoral activities in favour of themselves or their personal network, this concerns mainly local and national politicians: "(...) authority dates the eyes and often turns our faces to the investors, we make noise but sometimes it has no echo because the millions speak louder on the island" (URHRNB48, 2014). A significant part of this perception stems from the distrust of the sale and expropriation of public and private land from national and regional authorities to investors and from its pressure on real estate speculation. This perception is particularly significant between the age group 60-69 years, those who saw the relationship with land and its properties change dramatically, as well, by those who have intermediate (preparatory and secondary) education, and practically ignored by the younger residents who do not own or owned property.

The "increased pollution" refers to environmental problems, but also to the lack of basic infrastructure infrastructures associated with tourism activity (Jurowski \& Gursoy, 2004; Northcote \& Macbeth, 2005). Only the 30-39 and 40-49 age brackets refer this impact, which is surprising and aggravates the fact that other positive and negative impacts on the environment are ignored by almost all interviewed. This reflects a deep lack of knowledge about the environmental impacts promoted by tourism, many of them distant from both tourists and resident's eyes. For example, several tons of garbage are dumped daily in an open dump near the country's largest river basin: "There is no separation of organic and non-organic garbage here, everything goes to the bin. What you can burn, burn, the rest is there!" (URHREB36, 2014). In fact, only those interviewed whose profession is related to environmental protection refer to the environmental impacts of tourism on the island. 
To reinforce this idea, the impact of "destruction of nature" is statistically significant when we find that only the foreigners mention it, just as in the resident group are the foreign residents and operators who mention it, that is, the Cape Verdeans clearly devalue the environmental impacts despite of the dangers already mentioned: "The island is small and fragile, or we end up with everything good, like turtles, or else we have to produce beaches ... the ecosystem is completely weakened" (URHRNB62, 2014).

He next perception is the "loss of authenticity" which refers to the aforementioned question of the craft shops and the production of souvenirs: "In the craft there is a lot that comes from outside, it is not from the island. They buy cat for hare!" (FFMRNB38, 2014), and also for the ways of representation of the national cultural in the hotels, in particular in the entertainment activities of the tourists, where performances are created that implies an inexistent connection or resemblance between activities and traditions of the African continent and the Cape Verdean traditions. Something that is particularly important in rural areas, where the changes promoted by tourism are strongly criticised.

In the same vein, the "Changes to Morality" are a negative impact perceived and especially highlighted by Cape Verdians: "The Boavistense is on the verge of extinction!" (URHRNOI34, 2014). They consider that the abrupt and persistent changes to the codes of conduct, values and rules that arose as a result of the intense tourist activity forced transformations that displease the natives of the archipelago and destroy their culture. Such national and foreign pressure on communities is also present in the results of other researchers (Turner \& Ash, 1975; Brunt \& Courtney, 1999; Tomljenovic \& Faulkner, 2000).

The negative impact of "Real Estate Speculation" is explicit and reinforces the idea that the demand for tourism properties such as the demand for housing by migrants has produced a price hike and enormous pressure on the island's fragile real estate market by forcing the regional and national government to build social housing and ignore the construction of two slums: "It looked like the gold fever! People only talked about land plots (...)." (URMRNB27, 2014). Statistically, men who traditionally manage and own property, but also those with higher levels of education (secondary or higher education), are more aware of this impact.

The absence of the secondary sector and the insipidity of the primary sector on the island, the tertiary sector, particularly tourism, absorb much of the country's available labour force. The success of tourism in the country and island is clear and an example is the average occupancy rate of all-inclusive hotels that is above $80 \%$, but as a result many interviewees refer as negative impact "Tourism Dependency": "The country has always been dependent on development aid, always dependent on emigrants' remittances, and now it is also completely dependent on tourism itself!" (URHRNB28, 2014). Of the several groups tested only the gender variable proved to be significant. As in the previous impact, the male gender was the only one to mention this perception, an impact is also present in Ferreira (2005) or Lopes (2008) among others.

Finally, the last negative impact, "Discrimination towards Migrants", which refers to the treatment and discriminatory attitude among the Boa Vista groups, in particular the natives towards national migrants and foreign emigrants: "People who emigrate to here are not the best! Anything goes, robbery, assault!" (URFRNB33, 2014). The island had 4 thousand inhabitants at the end of last century and in little more than 3 years its population tripled, and now the residents are a minority. These migrants and immigrants are viewed with suspicion and concern, and are associated with crime and immoral practices. Part of this attitude resulted from the aforementioned slums that have arisen and where many of these migrants live. The data show that only the variable "area of residence" has shown to be significant, namely the inhabitants in rural areas emphasize this perception. Today, the physical and symbolic division between these groups has been blurred with the construction of social housing and with the gradual and continuous contact between groups.

In sum, the results show, on the one hand, that only a positive economic impact and a perceived social positive impact were found to be statistically relevant, and that on the other, two economic and eight social negative impacts were mentioned, reinforcing the idea that there is a predominantly negative perception focused on social issues, again only one environmental impact mentioned was statistically relevant. It is now the moment to discuss its implications and draw conclusions from the results.

\section{Discussion}

This research explores the results obtained contextualizing the object of study and presenting original results that reflect a social reality underlining some key variables and opening the way to the discuss their implications. At this point, we intend to discuss the relationship of these results with the governance issue of Boa Vista, and Cape Verde. 
Tourism can be a driver of social change or at least a contributor to such a change (Brunt \& Courtney, 1999), which tends to accelerate or force social and cultural change (Vounatsou et al., 2015), and may even be mistaken as responsible for changes that result from other larger and more complex processes (Crick, 1989). Still, the vast changes that Cape Verde has felt in the last decades find much of their origin in the bet on international tourist.

In Boa Vista it seems evident that precisely such changes contribute to and influence the perceptions of its residents, conditioning and favouring strategies of resistance and reinforcement in the wake of a new conjuncture (Bernardo, 2015a, Bernardo, 2015b), but it is important to look at these perceptions as proof of something else. We refer to the deconstruction of the idea that local communities, not specialists or professionals in tourism, are unable to identify and determine strategies and impacts on destinations. Our study demonstrates that the perceived impacts approach or even coincide with those identified by experts, which leads us to argue that for a destination to be successful and sustainable, communities must be represented and involved in their planning.

We are talking about tourism governance, sustainability and tourism policy. The latter as a set of rules, guidelines, objectives and strategies that are intended to be implement in a destination (Goeldner, Ritchie \& McIntosh, 2000). A destination that seeks to be sustainable in all its dimensions, that is, also considering the technological and political pillars (HwanSuk \& Sirakaya, 2006). An integrated and transparent management (Timur \& Getz, 2002), capable of relating different administrative structures to a modern governance application (Paskaleva, 2003). A commitment between stakeholders, state, communities, operators and tourists. The tourism governance platform recognizes the role of these three dimensions and seeks to design, implement and apply the joint strategy for a tourism destination (Hall, 2000; Healy, 1997).

If governance is the appropriate mechanism for transparent governance on the part of public and private institutions where the goal is planned sustainable development (Tornell \& Lane, 1999). Tourism governance adds the recognition of the need for adaptation. Tourist destinations are not all the same so all of them should be able to adjust in order to prevent impacts already experienced by numerous other destinations, equally, should consider a holistic approach to planning and development.

In the island of Boa Vista we find many barriers to government that makes it difficult to implement a traditional vertical strategy. An incomplete constitution, party-political struggles, absence of a public body for tourism management and planning, and mismanagement at regional level, boycott transparent, efficient and effective public intergovernmental governance (Bernardo, 2015c). From governing to governance implies abandoning obsolete structures and recognizing the central role of communities in the sustainable development of destinations (Murphy, 1985; Lankford, 1994).

As Andriotis (2005) concluded in his research, we also find in Boa Vista a local and business community with a high capacity to define objectives and solutions to the problems experienced on the island. Their valuable inputs, here in the form of collected perceptions, can contribute to a redefinition of regional tourism strategy. Many other studies have demonstrated how community involvement can lead to the minimization of many negative impacts (Pearce, 1998; Brunt \& Courtney, 1999; Cooper et al., 2006).

Sustainable tourism requires closer links between the public and private sectors (Brida et al., 2011) and the island of Boa Vista is an example of this. As our results point out, the residents' perceptions of the impacts of tourism, in particular their origin and / or justification, allow a deeper understanding of the reality lived. This, in turn, adds valuable and fundamental information for the redefinition of the strategy and sustainable tourism planning for the island, otherwise we are destined to repeat past mistakes.

Local residents, their communities, are an essential part of the success of a tourist destination that can't be replaced or simulated by external entities, evaluators, or official statistics from any government. Their participation and involvement are inseparable from the success of tourism and local development. It is urgent to create a public and transparent platform that allows all stakeholders to participate in the future of Boa Vista as a tourist destination, correcting the route taken. Continuing to ignore the evidence will only perpetuate the problems and impacts resulting from the strategy plan implemented thus so far.

\section{Conclusion}

This article shared and analysed a set of perceptions of tourism impacts of Boa Vista residents in Cape Verde, however, its main objective was to demonstrate how these same residents are able to clearly identify the advantages and disadvantages of implementing a development strategy based on mass tourism. 
Equally important was to understand how these perceptions are related to the knowledge and daily experience of those who live in tourist destinations, and how they do not differ from the impacts detected and referenced by scientific literature and professional experts in other destinations. This same capacity to identify impacts reinforces the idea that communities have an important say in the planning and implementation of tourism development strategies, even in low literacy communities, low economic conditions and in peripheral conditions.

It is clear that tourism governance, based on the participation of all stakeholders, including communities, is the key to countering the negative impacts and enhancing the positive impacts, not only because involving a community increase their positive perception of tourism activity and, consequently, the attitude of residents towards tourists, but because communities have a role to play and a knowledge to share that must be considered. This involvement requires rejecting the politicized stance of disguised community participation by public entities, public institutions and the private sector. Communities must be represented and actively involved in all phases of tourism planning, implementation and monitoring.

\section{Limitations}

The current article lacks a comparative and in depth with other destinations, namely in the same country, in order to better explains its results. Also the quantitative analysis of the data collected through qualitative methods may incur on a selective and narrow view, not considering important and vital information that is not representative quantitative.

\section{Bibliography}

Akis, S., Peristianis, N., Warner, J.

1996. "Residents' attitudes to tourism development: the case of Cyprus", Tourism Management, 17: 481-494.

Konstantinos, A.

2005. "Community Groups' Perceptions of and Preferences to Tourism Development. Evidence from Crete", Journal of Hospitality and Tourism Research, 29(1): 67-90.

Azarya, V.

2004. "Globalization and International Tourism in Developing Countries: marginality as a commercial commodity”, Current Sociology, 52(6): 949-967.

Bernardo, E.

2015. Perceção dos Impactos do Turismo na ilha da Boa Vista, Cabo Verde. Doctoral Thesis. ISCTE-IUL: Lisbon.

Bernardo, E.

2015b. "Das Perceções ao Futuro na Boa Vista - atitude e perspetivas num destino turístico caboverdiano",

Revista Turismo e Desenvolvimento, 24: 97-101. ISSN 1645-9261, UA: Aveiro.

Bernardo, E.

2015c. "Planeamento Turístico e Impactos Percecionados na ilha da Boa Vista, Cabo Verde", Revista

Turismo em Análise, 26(4), USP: São Paulo (http://www.revistas.usp.br/rta/article/view/89408)

Brida, J., Monterubbianesi, P., Zapata-Aguierre, S.

2011. "Impactos del Turismo sobre el Crecimiento económico y el desarrollo. El caso de los principales destinos turísticos de Colombia". Pasos - Revista de Turismo y Património Cultural, 9(2): 291-303.

Brown, G., Giles, R.

1994. "Resident responses to the social impact of tourism", Seaton, et al. (Ed.), Tourism: A state of the art, pp. 755-764, Chichester, Wiley.

Brunt, P, Courtney, P.

1999. Host Perceptions of Sociocultural Impacts, Annals of Tourism Research, 26(3): 493-515.

Chen, C., Chhabra, D., Tatsugawa, K.

2004. "Resident Perception of the Effect of Tourism - A Case Study", e-Review of Tourism Research (eRTR), 2(4): 82-87.

Cooper, C., De Lacy, T., Jago, L.

2006. Development of a scale to assess the social impact of tourism within communities, The Sustainable

Tourism Cooperative Research Centre (STCRC), Fredline, Australia. 
Crick, C.

1989. "Representations of International Tourism in the Social Sciences: Sun, Sex, Sights, Savins, and

Servility", Annual Review of Anthropology, 18: 44-307.

Ferreira, L.

2005. "Estudo Analítico das Variáveis da Macro Envolvente de uma Destino Turístico", Revista de Estudos Politécnicos, 2(4): 1\35-147.

Goeldner, C., Richie, B., McIntosh, R.

2002. Turismo Princípios, Prática e Filosifia, $8^{a}$ Ed. Porto Alegre, Bookman.

Hall, M.

2000. Tourism Planning: Policies, Processes and Relationships. Pearson Education. Healy, Paul. 1997.

Collaborative Planning: Shaping Places in Fragmented Societies. Basingstoke: MacMillan Press.

Hair, J., Black, W., Babin, B., Anderson, R., Tatham, R.

1998. Multivariate data analysis, 5(3): 207-219. Upper Saddle River, NJ: Prentice hall Hair.

Hwansuk, C., Sirakaya, E.

2006. "Sustainability indicators for managing community tourism", Tourism Management, 27: 1274-1289.

Jurowski, C., Gursoy, D.

2004. Distance effects on residents' attitudes toward tourism, Annals of Tourism Research, 31(2): 296-304.

Kakazu, H.

2007. "Sustainable Island Tourism: The Case of Okinawa", University of the Ryukyus. Online at: http:// www.yashinomi.to/pacific/pdf/Kakazu_02.pdf

Lankford, Samuel

1994. "Attitudes and perceptions toward tourism and rural regional development", Journal of Travel

Research, 32(2): 35-43.

Lopez-Guzman, T., Ribeiro, M., Agüera, F.

2015. El turismo en Cabo Verde, Perfil y valoración del viajero. Estudios y Perspectivas en Turismo, 24: $512-528$.

Lopes, L.

2008. "Os Impacto Socioculturais e o Desenvolvimento do Turismo Paleontológico em Peirópolis - Minas

Gerais", Centro Universitário de Belo Horizonte, dissertação de mestrado em Turismo e Meio Ambiente. Murphy, P.

1985. Tourism: A community Approach, New York, Routledge

Northcote, J., Macbeth, J.

2005. "Conceptualizing yield: Sustainable Tourism Management", Annals of Tourism Research, 33(1): 199-220.

Pearce D.

1998. Tourist organizations in Sweden. Tourism Management. 17(6): 413-424.

Redclift, M.

1992. "The Meaning of Sustainable Development", Geoforum, 23(3): 395-403.

Sarmento, E.

2008. O Turismo Sustentável como facto de desenvolvimento das pequenas economias insulares: o caso de Cabo Verde, Lisboa, Edições Universitárias Lusófonas.

Timur, S., Getz, D.

2002. Applying stakeholdertheory to the implementation of sustainable urban tourism, Karl Wober ed,

City Tourism 2002, Springer Economics.

Tomljenovic, R., Faulkner, B.

2000. "Tourism and World Peace: A Conundrum for the Twenty-first Century", Faulkner et al (Eds.).

Tourism in the Twenty-first Century, London: Continuum.

Tornell, Aaron, Philip Lane

1999. "The Voracity Effect", The American Economic Review, 89(1): 22-46.

Turner, L., Ash, J.

1975. The golden hordes: International tourism and the pleasure periphery, Constable, London.

Twining-Ward, L.

2010. "Cape Verde's transformation: tourism as a driver of growth". Working

paper, The World Bank, Washington D.C. 
Vellas, F., Cauet, J.

1997. Le Tourisme et les Îles, Economia, L'Harmattan, Paris.

Vounatsou, M., D. Laloumis, Nikolaos, P.

2005. "Social Impacts of Tourism: Perceptions of Mykonos' City Residents", International Conference on

Tourism Development and Planning, Patras, Greece. Disponível no sítio: http://tour.teipat.gr/Files/ Synedrio/Conferenc\%20Articles/Vounatsou_Paper.pdf 